\title{
Harmonising European Insolvency Law: The Emerging Role of Stakeholders
}

\author{
Gert-Zan Boon *广
}

Leiden Law School, University of Leiden, Netherlands

\begin{abstract}
In recent years, the European Commission has given increased room for stakeholder involvement in the area of insolvency and restructuring. In revising the European Insolvency Regulation in 2012-2015 and preparing the proposal for a directive on preventive restructuring frameworks 2016, the role and direct influence of stakeholders has been noteworthy. In these efforts, the Commission touched upon a field of law characterised by diverse stakeholders with strongly opposing interests. Following the active involvement of all stakeholders by the Commission, this study examines what relevant stakeholders are, what their positions are with respect to European Union insolvency legislation and what their role has been and can be in legislative processes in the area of insolvency and restructuring. Copyright (C) 2018 INSOL International and John Wiley \& Sons, Ltd.
\end{abstract}

\section{Introduction}

Since the 2011 call of the European Parliament for legislative measures with regard to insolvency proceedings in the context of EU company law, ${ }^{1}$ reform of insolvency regimes has been prominent on academic and legislative agendas. ${ }^{2}$ In subsequent efforts, the Commission acted in a largely untapped area of harmonising substantive insolvency law. A field of law characterised by diverse stakeholders with strongly opposing interests, including, among others, the debtor, the debtor's management, shareholders, employees, financiers, secured and

\footnotetext{
*E-mail: j.m.g.j.boon@law.leidenuniv.nl

${ }^{\dagger}$ For this chapter, the developments with regard to harmonisation of European insolvency law have been stated as per 1 January 2018. At the same date all internet sources have been checked. The author is grateful to the comments of the two anonymous referees. The author also thanks Professor Bob Wessels for his comments on an earlier draft.
}

1. European Parliament Resolution of 15 November 2011 with recommendations to the Commission on insolvency proceedings in the context of EU company law $(2011 / 2006($ INI)).

2. Ian Fletcher and Bob Wessels, Harmonisation of Insolvency Law in Europe (Reports presented to the Nederlandse Vereniging voor Burgerlijk Recht (Netherlands Association of Civil Law)) (2012, Kluwer, Deventer). 
unsecured creditors and tax authorities. In its approach, the Commission actively involved all these stakeholders.

This article will discuss, what the author will call, the integrated stakeholder approach that the Commission pursues in harmonising European insolvency regimes. Both in its revision of the European Insolvency Regulation (2000) ${ }^{3}$ (EIR 2000) and in its work on a proposal for a directive on preventive restructuring frameworks; second chance and measures to increase the efficiency of restructuring; and insolvency and discharge procedures ('Restructuring Directive'), ${ }^{4}$ the role and direct influence of stakeholders is noteworthy. The questions in this article concern what is a relevant 'stakeholder', why is the Commission involving them and whether - and under which conditions - it is justified to involve stakeholders in designing and execution of EU insolvency legislation.

This article is organised as follows. Section II will introduce the topic of stakeholders in insolvency and will elaborate on some theories regarding stakeholders. A technique will be proposed to distinguish and rank different types of stakeholders based on their salience. Subsequently, in Section III, this approach will be applied to define stakeholders in the field of insolvency legislation. In Section IV, the sensibility of stakeholder involvement will be discussed by reviewing how the role of stakeholders in insolvency law has evolved over time. Then, in Section V, the approach of the European Commission toward harmonising substantive insolvency and stakeholders will be discussed. Section VI will turn to the sentiments of different stakeholders on harmonisation. This will be followed by some recommendations to pursue, with the involvement of stakeholders, the Commissions' aim of harmonising certain aspects of national insolvency regimes (Section VII). Finally, Section VII draws some conclusions.

\section{Exploration of the Stakeholder}

The relevance of stakeholder involvement in the field of insolvency was advocated by, for example, EU Commissioner Věra Jourová. The EU Commissioner for Justice, Consumers and Gender Equality touched upon this in her speech of 16 June 2016 held at the occasion of the 5th European insolvency and restructuring congress where she spoke on the harmonisation process of European insolvency law. The EU Commissioner emphasised the important role of practitioners and judges to bring legislation alive and bring forward the benefits of legislation to the whole of the internal market. But their involvement is also required in designing new legislation. In particular, in drafting the new legislative instrument on substantive insolvency law, EU Commissioner Věra Jourová stated:

3. Council Regulation (EC) No. 1346/2000 of 29 May 2000 on insolvency proceedings ('EIR 2000') was revised by the adoption of Regulation (EU) 2015/848 of 20 May 2015 on insolvency proceedings (recast) ('EIR 2015').

4. European Commission, Proposal for a Directive of the European Union and the Council on preventive restructuring frameworks, second chance and measures to increase the efficiency of restructuring, insolvency and discharge procedures and amending Directive 2012/30/EU of 22 November 2016, COM(2016) 723 final ('Restructuring Directive'). 
It will build on the 2014 Recommendation and designed based on the input receive[d] from all concerned stakeholders, including you the practitioners, and from other Member States experts. We'll duly consider such input also in order to assess the state of play on consumer insolvency and whether action is needed in this regard. ${ }^{5}$

Furthermore, more recently, the Commissioner said:

In our preparatory work, we paid attention to the opinions of all stakeholders, including national parliaments. ${ }^{6}$

These quotes illustrate and emphasise the importance the Commission has attached to involve all stakeholders in its insolvency endeavour. At the same time, it is left open what these 'stakeholders' are. Although the Commissioner refers to, among others, insolvency practitioners, national parliaments and Member State experts, this seems a non-exhaustive list of stakeholders and leaves much room for interpretation. But also, what role do these stakeholders fulfil; are they a sounding board for the Commission's policies or even a strategic partner for new legislation?

\section{A. Stakeholders and corporate governance}

In the field of business administration and corporate governance, research has been conducted on what stakeholders are, how different stakeholders can be distinguished and how the interests of different stakeholder should be prioritised. The line of approach taken here is built, in particular, around the well-known divide ${ }^{7}$ between the shareholder primacy (corresponding to the agency theory ${ }^{8}$ ) and the (non-shareholder) stakeholder perspective and the alternative of the enlightened shareholder value. ${ }^{9}$

5. Speech by Commissioner Jourová at 5th European Insolvency and Restructuring Congress, Brussels (16 June 2016), available at: <http://ec.europa.eu/commission/2014-2019/jourova/announcements/speechcommissioner-jourova-5th-european-insolvency-andrestructuring-congress_en $>$.

6. Speech by Commissioner Jourová to the Legal Affairs Committee and EU Affairs Committee in the Bundestag: Anti-Money Laundering, European Public Prosecutor's Office, Digital Contracts and Insolvency (26 September 2016), SPEECH/16/3189, available at: <http://www.europa.eu/rapid/press-release_ SPEECH-16-3189 en.htm >.

7. See David Millon, 'Radical Shareholder Primacy' (2013) 12(4) University of St. Thomas Law Fournal 1013. Millon describes two types of shareholder primacy, (i) the radical shareholder primacy where directors are fully focused on serving the shareholders' interests and (ii) the traditional shareholder primacy, where directors consider interests of shareholders and (where appropriate) that of non-shareholders. Vasudev and Watson refer to this divide as the 'Great Debate': P.M. Vasudev and Susan Watson (eds), Corporate Governance after the Financial Crisis (2012, Edward Elgar, Cheltenham), 6. See also Jonathon Strom, 'The Rebirth of Heroic Managerialism' (2015-2016) 3 Bus. \&̊ Bankr. L. 7. 67, 69 et seq.

8. Michael Jensen and William Meckling, 'Theory of the Firm: Managerial Behavior, Agency Costs, and
Ownership Structure' (1976) 3(4) Fournal of Financial Economics 305.

9. The enlightened shareholder value (ESV) is based on shareholder primacy but advocates long-term profit and incorporates interests of shareholders and other stakeholders. For example, see David Millon, 'Enlightened Shareholder Value, Social Responsibility, and the Redefinition of Corporate Purpose without Law' (Washington \& Lee Legal Studies Paper No. 201011), available at: <http://ssrn.com/abstract= 1625 750>; Virginia Harper Ho, "Enlightened Shareholder Value": Corporate Governance Beyond the Shareholder-Stakeholder Divide' (2010) 36(1) Fournal of Corporation Law 59. For a review of 10 years of ESV, as incorporated in the UK Company Act, see Sabrina Bruno, 'The "Enlightened Shareholder Value" in UK Companies Ten Years Later: What the European Directive N. 2014/95/EC Can Do' in Anne Dorsman et al. (eds), Le Droit Comparé des Affaires au XXIéme siècle (Mélanges à la mémoire de Claude Ducoloux-Favard) (Larcier, 2017) (315-327). Furthermore, Baumfield argues that stakeholder theory, as conceived by management theorists, is largely in line with ESV and does not conflict with shareholder wealth maximisation: Victoria Baumfield, 'Stakeholder Theory from a Management Perspective: Bridging the Shareholder/Stakeholder Divide' (2016) 31 Australian Journal of Corporate Law 187. 
In 2014, the Commission published a proposal to revise two directives on encouraging long-term shareholder engagement and corporate governance. ${ }^{10}$ Here, they promote the involvement of both shareholders and other stakeholders in a company. The European Parliament, in response, took this a step further and suggested to include the position of all stakeholders of the company ('EP Amendment'). ${ }^{11}$ Regarding shareholders, the text should explicitly state (emphasis added):

(2) Although they do not own corporations, which are separate legal entities beyond their full control, shareholders play a relevant role in the governance of those corporations.

[...] (2a) Greater involvement of shareholders in companies' corporate governance is one of the levers that can help improve the financial and non-financial performance of those companies. Nevertheless, since shareholder rights are not the only long-term factor which needs to be taken into consideration in corporate governance, they should be accompanied by additional measures to ensure a greater involvement of all stakeholders, in particular employees, local authorities and civil society. ${ }^{12}$

With this proposal, the European Parliament declines, more explicitly than the Commission did, the shareholder primacy perspective, as shareholders are no longer regarded as the owners of companies. However, in the subsequent steps of the legislative process, these amendments were not included. In the final text as adopted in the Directive, it was, however, reiterated not only that greater shareholder involvement can play a role in improving (non-)financial performance of a company but also that it is important to involve other stakeholders in corporate governance. ${ }^{13}$ The EP Amendment and the final text of the Directive do not provide for a definition of what corporate governance is in this context. However, there are numerous definitions available. See, for example, the well-known 1992 Cadbury Report on Corporate Governance, which states:

Corporate Governance is the system by which companies are directed and controlled. ${ }^{14}$

10. European Commission, Proposal for a Directive of the European Parliament and of the Council amending Directive 2007/36/EC as regards the encouragement of long-term shareholder engagement and Directive 2013/34/EU as regards certain elements of the corporate governance statement, 9 April 2014, 2014/0121 (COD). Both the directives themselves and this proposal hardly touch upon the position of stakeholders other than shareholders.

11. European Parliament, Amendments adopted by the European Parliament on 8 July 2015 on the proposal for a Directive of the European Parliament and of the Council amending Directive 2007/36/EC as regards the encouragement of long-term shareholder engagement and Directive 2013/34/EU as regards certain elements of the corporate governance statement (COM(2014)0213-C7-0147/2014-2014/ 0121(COD)) (Ordinary legislative procedure: first reading), P8_TA(2015)0257.

12. Ibid., (2). See also Jean-Jacques Du Plessis, 'Corporate Governance, Corporate Responsibility and Law: Shareholder Primacy and Other Stakeholder Interests' (2016) 34(8) Company and Securities Law Fournal 238.

13. See Directive (EU) 2017/828 of 17 May 2017 amending Directive 2007/36/EG as regards the encouragement of long-term shareholder engagement, Recitals 2, 14 and 16. With still a central role for the shareholder, this Directive seems to apply the aforementioned ESV approach.

14. Report of the Committee on the Financial Aspects of Corporate Governance (Cadbury Report) (1992), paragraph 2.5, available at: <http://cadbury.cjbs. archios.info/report>. 
The Cadbury Report applies a functional and abstract approach to define corporate governance. It focuses on the company's structure. Another respected definition is that of the G20/OECD, which also includes a relational perspective by incorporating the role of stakeholders in corporate governance:

Corporate governance involves a set of relationships between a company's management, its board, its shareholders and other stakeholders. Corporate Governance also provides the structure through which the objectives of the company are set, and the means of attaining those objectives and monitoring performance are determined. ${ }^{15}$

From the aforementioned G20/OECD definition, it can be observed that corporate governance does not relate only to internal but also to external stakeholders. It also recognises their importance in both setting and achieving company objectives. As such, this definition seems effective in explaining the role in a company's corporate governance and can be guidance to analysing governance in the context of a legislative process.

\section{B. Defining stakeholders}

The G20/OECD report provides a useful definition of corporate governance but leaves it open what stakeholders are. Here, we can return to the EP Amendment, as various suggestions are proposed to promote that, besides the interests of shareholders, ${ }^{16}$ also interests of other stakeholders are kept by a company. ${ }^{17}$ Interestingly, the EP Amendment proposes a definition of a company's stakeholders (in particular employees, local authorities and civil society), ${ }^{18}$ which reads as follows:

any individual, group, organisation or local community that is affected by or otherwise has an interest in the operation and performance of a company. ${ }^{19}$

15. G20/OECD Principles of Corporate Governance (2015), 9, available at:<https://www.oecd.org/corporate/principles-corporate-governance.htm $>$. For a more extensive review of some definitions of corporate governance, see Bernard Santen, On the Role of Monitoring near Financial Distress (201 1, diss.), paragraphs 3.2.2-3.6. 16. Shareholder is defined as: 'the natural or legal person that is recognised as a shareholder under the applicable law': Directive 2007/36/EC of 11 July 1997 on the exercise of certain rights of shareholders in listed companies, Article 2(b). 17. Ibid., inter alia Recitals (8), (10), (18); Article 3 h(2)(d). 18. For civil society, no definition is provided by the European Parliament in this proposal, nor who will represent these interests (to the company). The United Nations regards 'civil society' as the third sector, besides the government and business, comprising the whole of non-governmental and not-for-profit organisations, see United Nations, Civil Society (2016), available at: $<$ www.un.org/en/sections/resources/civil-society $>$. The World Bank defines civil society as follows: 'the wide array of non-governmental and not-for-profit organizations that have a presence in public life, expressing the interests and values of their members or others, based on ethical, cultural, political, scientific, religious or philanthropic considerations. Civil Society Organizations (CSOs) therefore refer to a wide of array of organizations: community groups, non-governmental organizations (NGOs), labour unions, indigenous groups, charitable organisations, faith-based organizations, professional associations, and foundations': World Bank, Defining Civil Society (2016), available at: <http:// go.worldbank.org/4CE7W046K0>.

19. European Parliament, Amendments adopted by the European Parliament on 8 July 2015 on the proposal for a Directive of the European Parliament and of the Council amending Directive 2007/36/EC as regards the encouragement of long-term shareholder engagement and Directive 2013/34/EU as regards certain elements of the corporate governance statement (COM(2014)0213-C7-0147/2014-2014/ 0121(COD)) (Ordinary legislative procedure: first reading), P8_TA(2015)0257, Article 1(2)(jb). This definition was not included in the final text of the adopted Directive (EU) 2017/828. 
Various other definitions of 'stakeholder' can be found in academic literature. ${ }^{20}$ Parliament's definition seems in line with Freeman's perspective of stakeholders of 1984, although he takes a stronger emphasis on the companies' strategy and purpose:

A stakeholder in an organization is (by definition) all of those groups and individuals, that can affect, or are affected by, the accomplishment of organizational purpose. ${ }^{21}$

A more invasive perspective on stakeholders is proposed by Savage, Nix, Whitehead and Blair (1991), as they define stakeholders as follows:

Stakeholders include those individuals, groups, and other organizations who have an interest in the actions of an organization and who have the ability to influence it. ${ }^{22}$

According to Savage et al., stakeholders need to have both (i) an interest in the actions of an organisation, which arguably is present when an organisation's actions affect these interests, and (ii) be able to influence the organisation. This is a more stringent definition compared with the definitions of the European Parliament and Freeman, where either (i) or (ii) would suffice to qualify as stakeholder.

In light of the previous text, there would in general be two (not mutually exclusive) types of stakeholders from the perspective of the legislative 'business' of the European Commission on insolvency law: (i) all those individuals and groups that can affect the drafting process of a legislative measure on insolvency law, in particular the Council, the Parliament and the Member States and (ii) all those individuals and groups that are affected by a legislative measure on insolvency. This could include, among others, companies, employees, insolvency practitioners and judges. In its current insolvency endeavour, the Commission provides, in particular, these latter stakeholders with a strong but informal influence on the legislative process that therefore fall within the scope of stakeholders as defined by Savage et al. (1991).

\section{Distinguishing and ranking of stakeholders}

With a broad perspective on stakeholders, the inequality of interests makes it hard to compare the various stakeholders involved in insolvency. To distinguish 'who and what really counts', Mitchell, Agle and Wood (1997) have developed an approach based on salience. They propose that those interests that have the highest

20. Some prime definitions of stakeholder have been provided in this article. However, as has been rightly observed by Samantha Miles, there are numerous definitions and consensus on the concept of 'Stakeholder'. She even concludes that we could speak of 'stakeholder' as an essentially contested concept, see Samantha Miles, 'Stakeholder: Essentially Contested or Just Confused?' (2012) 108(3) Journal of Business Ethics 285. For an overview of some 27 definitions of 'stakeholder', see Ronald Mitchell, Bradley Agle and Donna Wood, 'Toward a Theory of Stakeholder Identification and Salience: Defining the Principle of who and what really counts' (1997) 22(4) Academy of Management Review 853, 858.
21. Edward Freeman, Strategic Management: A Stakeholder Approach (Pitman, 1984), 25.

22. Grant Savage et al., 'Strategies for Assessing and Managing Organizational Stakeholders' (1991) 5(2) Academy of Management Executive 61. They further distinguish between (i) primary stakeholders as the ones that have a direct and necessary economic impact on the organisation and (ii) secondary stakeholders as the ones that are only indirectly part of the company's business, but that can influence the company. To review the different stakeholders, two dimensions are proposed: (i) the potential threat they represent and (ii) the potential to cooperate with these stakeholders. 


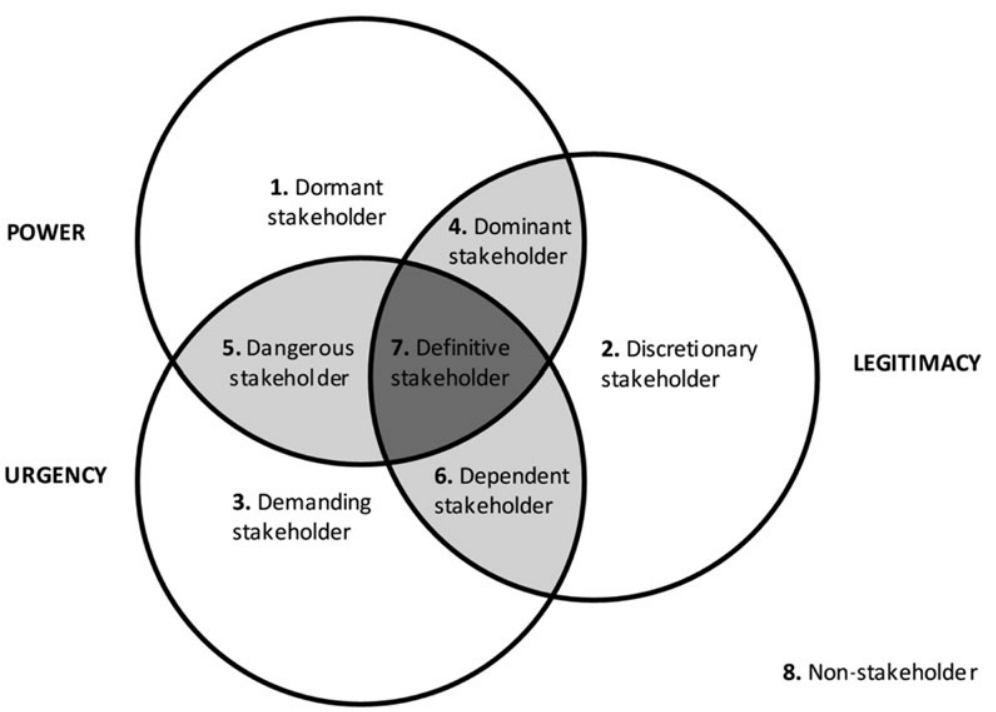

Figure 1. Qualitative classes of stakeholders. Source: Mitchell, Agle and Wood.

salience are the interests that should be given the most priority. Salience should be evaluated on three attributes, namely, (i) power, (ii) legitimacy and (iii) urgency: ${ }^{23}$

i Power relates to the possibility that someone can impose his will in a relationship upon (an) other(s). There can be a legal foundation to this power. ${ }^{24}$

ii Legitimacy relates to the (social) desirability of the interest (and accompanying behaviour) of a stakeholder as shared by others. ${ }^{25}$

iii Urgency relates to whether or not 'time is of the essence' for the interests at hand and whether compelling action is required. ${ }^{26}$

The combination of these three attributes results in eight different types of stakeholders (Figure 1). ${ }^{27}$

Mitchell, Agle and Wood propose the following typology of stakeholders:

1 Dormant stakeholder;

2 Discretionary stakeholder;

3 Demanding stakeholder;

4 Dominant stakeholder;

5 Dangerous stakeholder;

6 Dependent stakeholder;

7 Definitive stakeholder;

8 The non-stakeholder.

The more attributes a stakeholder possesses, the more priority should be given to a stakeholder. Besides 8 (the non-stakeholder), 1-3 (dormant, discretionary 
and demanding stakeholders) would receive the least attention, 4-6 (dominant, dangerous and dependent stakeholders) much more and 7 (definitive stakeholders) most attention. Applying this framework will be useful in distinguishing between various interests. At the same time, it leaves some room for subjectivity, for example, on whether or not a broad or narrow view is applied in recognising power, legitimacy and/or urgency of specific interests of stakeholders. ${ }^{28}$

\section{Conclusion}

The aforementioned showed the interrelatedness between a governance model and the involvement of stakeholders. This was illustrated with the perspectives of the Commission and the European Parliament. In the area of corporate governance, various definitions of stakeholders have been developed, in this section, the definition of Savage et al. (1991) was adopted, which requires stakeholders to have an interest in the organisations' action and be able to influence these actions:

Stakeholders include those individuals, groups, and other organizations who have an interest in the actions of an organization and who have the ability to influence it. ${ }^{29}$

These perspectives on corporate governance can also be used to analyse the governance of a legislative process. EU Commissioner Věra Jourová pointed out the importance of involving all stakeholders in its current endeavour on the harmonisation of substantial insolvency law, thereby advocating a stakeholder perspective on legislative governance. It remains, however, undecided who these stakeholders are and what their role should be in this legislative process. The aforementioned framework provides a qualitative tool for the evaluation of who possible stakeholders are and what their position is compared with other stakeholders. Where, following the Commission's approach, besides legislative parties (such as the European Parliament, Council and Member States), other parties are also recognised as stakeholders (e.g. employees and civil society), an approach based on salience of interests may be effective in prioritising the different stakeholders. This differentiation can be based on three attributes: (i) power, (ii) legitimacy and (iii) urgency. The more attributes a stakeholder possesses, the more important its interests are. This forms a starting point in distinguishing between the many conflicting interests involved in legislative processes.

\section{Stakeholders in Insolvency and Restructuring}

As mentioned before, governance also plays a key role where it concerns the extent to which internal and external stakeholders are involved in a legislative process, which in this article will be referred to as 'legislative governance'. Where it

28. Ibid., 856.

29. Savage et al., previous note 22, 61, further distinguishing between (i) primary stakeholders as the ones that have a direct and necessary economic impact on the organisation and (ii) secondary stakeholders as the ones that are only indirectly part of the companies' business, but that can influence the company. To review the different stakeholders, two dimensions are proposed: (i) the potential threat they represent and (ii) the potential to cooperate with these stakeholders. 
concerns the legislative efforts of the Commission on harmonising insolvency and restructuring laws, stakeholders can be defined based on the definition of Savage et al. (1991), as follows:

Stakeholders are all those individuals, groups and other organisations that have an interest in the EU legislative process of harmonising insolvency and restructuring law and which have the ability to influence the choices and decisions the Commission has to make.

The ability to influence the legislative process is presumed present for all individuals, groups and other organisations that have taken (actively) part in any of the activities that the Commission has employed, as will be elaborated in Section VI, and represent interests that are affected by insolvency and restructuring proceedings. For legislative governance, in particular 'power' and 'legitimacy' are important attributes, as described by Mitchell et al. (1997), for stakeholders to affect legislation. For the attribute 'urgency', this is different. Urgency will in the course of a legislative process not be an attribute likely present with stakeholders in general. Therefore, in the area of on insolvency and restructuring proceedings, a distinction can be made between three types of stakeholders with the following non-exhaustive overview of stakeholders.

\section{A. Dominant stakeholders (attributes: power and legitimacy)}

Stakeholders for whom power is based on a statutory provision include

- European Parliament;

- European Council;

- Member States.

Power can also be based on the direct involvement and central role played by certain stakeholders in realising a successful restructuring:

- Banks and other institutional investors;

- Non-institutional investors;

- Secured creditors.

\section{B. Discretionary stakeholder (attribute: legitimacy)}

Legitimacy for various stakeholders is based on their direct involvement in insolvency and restructuring proceedings, as is the case for

- Debtors;*

- Shareholders;

- Trade creditors;

- Employees;

- Tax authorities;*

- Judiciary;*

- Practitioners (insolvency practitioners, ${ }^{*}$ mediators, supervisors, CROs, turnaround professionals).

Copyright (C) 2018 INSOL International and John Wiley \& Sons, Ltd Int. Insolv. Rev., Vol. 27: 150-177 (2018) 
* While these stakeholders have no statutory power to draft legislation, they can, based on different grounds, have some informal power due to their direct involvement on insolvency and restructuring proceedings.

For other stakeholders, legitimacy is based on the indirect involvement in insolvency and restructuring proceedings, as their involvement is professional or based on representation of interests:

- Accountants;

- Lawyers (including barristers, solicitors, attorneys-at-law, etc.);

- Labour unions;

- Business Associations;

- Trade Unions.

\section{Dormant stakeholders (attribute: power)}

Informal power based on independent expertise applies to these stakeholders:

- The Commission's Group of Experts on Restructuring and Insolvency Law; ${ }^{30}$

- Academics;

- International Monetary Fund;

- United Nations Commission on International Trade Law (UNCITRAL);

- World Bank.

The aforementioned overview shows in part a divide between the formal legislative stakeholders versus the 'other stakeholders'. Although some of these other stakeholders may have a powerful informal position, from a strict legal perspective, this is of secondary importance to that of the legislator. However, as Vera Jourová stated too, in particular, some of these other stakeholders are the ones 'to apply the new rules as well as help deliver the benefits to the Single Market'. 31

\section{Conclusion}

In this section, 'legislative governance' is introduced as the governance of a legislative process in which a legislator engages with internal and external stakeholders. In the Commission's legislative governance regarding substantive insolvency law, stakeholders can be defined as:

Stakeholders are all those individuals, groups and other organisations that have an interest in the EU legislative process of harmonising insolvency and restructuring law and which have the ability to influence the choices and decisions the Commission has to make.

In the field of legislation, ranking of diverse interests of stakeholders can be based on two out of the three attributes defined by Mitchell et al. Stakeholders

30. This group has been initiated by the European Commission, with the aim of assisting the Commission in its work on a legislative proposal on substantive insolvency law. See http://ec.europa.eu/transparency/
regexpert/index.cfm?do=groupDetail. groupDetail\&groupID=3362.

31. Speech by Commissioner Jourová, previous note 5 . 
can be characterised by their 'power' and/or 'legitimacy', but in general, not with 'urgency'. Different groups of stakeholders can be distinguished. The formal legislative stakeholders (e.g. the Parliament, Council or Member States) are referred to as dominant stakeholders with power and legitimacy of their interests. Other stakeholders can have direct (e.g. debtor, shareholders or employees) or indirect (e.g. insolvency practitioners or accountants) legitimacy of their interests (the so-called discretionary stakeholders). Dormant stakeholders are characterised by the power of their interests (e.g. academia). Whereas this approach of prioritising interests shows the strength of certain interests, it gives no substantive judgement on the value of specific interests.

\section{The Emerging Role of Stakeholders in Insolvency}

Some tendencies have strengthened the role of stakeholders in the field of restructuring and insolvency law, which include (i) the changing scope of insolvency regimes, (ii) the shifting focus of EU harmonisation of insolvency matters and (iii) the quest for rescuing financially distressed businesses.

\section{A. The changing scope of insolvency regimes}

Traditionally, interests of creditors were the most important interest for insolvency regimes. This makes sense as insolvency regimes were primarily aimed at ensuring equal treatment of creditors and maximising the value of the insolvent debtor's estate. ${ }^{32}$ Nowadays, it still is the primary interest of most insolvency regimes in Europe, although their scope is extending to include, often of secondary importance, the interests of the debtor, employees and civil society. ${ }^{33}$

In theory, distinctions have been made between different approaches of insolvency regimes, including the creditor bargaining approach and the social benefit approach. The creditors' bargaining approach regards the common pool problem of limited funds. In the context of insolvency law, the focus is on maximising the value solely for creditors. The social benefit approach proclaims that laws should serve various interests of society, which would otherwise not have been treated fairly and equal, a 'forum in which competing and various interests and values accompanying financial distress may be expressed and sometimes recognized'. ${ }^{34}$

Recent developments in EU legislation have shown that the social benefit approach is getting more influence. For instance, the EIR 2000 makes no references to 'stakeholders', 'civil society' and 'employees'. This changed with the EIR 2015,

32. See, for example, Louis Levinthal, 'The Early History of Bankruptcy Law' (1918) 66(5) University of Pennsylvania Law Review 223; Karl Gratzer and Dieter Stiefel (eds), 'History of Insolvency and Bankruptcy from an International Perspective' (2008) 38 Södertörn Academic Studies 6.

33. See, for example, on the Netherlands: René Orij and Gert-Jan Boon, 'Stakeholderbelangen bij bedrijven in zwaar weer: perspectieven op financiële en niet-financiële belangen' in Jan Adriaanse, Dick van Offeren and Jean-Pierre van der Rest, 'Turnaround Management, Recht en Praktijk' (Kluwer, 2016) (153-172).

34. David Morrison and Colin Anderson, 'The Australian Corporate Rescue Provisions: How do they Compare?' in Paul Omar (ed), International Insolvency Law: Reforms and Challenges (Ashgate, 2013), 179 et seq. 
which makes some references to employees and the protection of jobs. ${ }^{35}$ It was the Commission's Recommendation on a new approach to business failure and insolvency (Recommendation) that emphasises a broad group of interests (underlining added):

The objective of this Recommendation is to ensure that viable enterprises in financial difficulties, wherever they are located in the Union, have access to national insolvency frameworks which enable them to restructure at an early stage with a view to preventing their insolvency, and therefore maximise the total value to creditors, employees, owners and the economy as a whole. ${ }^{36}$

A particular landmark was the UNCITRAL Model Law on Cross-Border Insolvency Law 1997 ('UNCITRAL Model Law') that provides a global set of rules for implementation in national laws on cross-border insolvency cases. ${ }^{37}$ The UNCITRAL Model Law was designed to achieve a 'global solution for all stakeholders of an insolvency proceeding' and is designed also for 'maximizing outcomes for all stakeholders'. 38

Another non-European illustration of promoting stakeholder involvement can be derived from the USA where in 2014 the American Bankruptcy Institute (ABI) presented a report (ABI Report) following an extensive study on a potential reform of the US Chapter 11 Bankruptcy Code on reorganisation proceedings. The objective of the working group for the ABI Report was to (emphasis added):

[...] propose reforms to Chapter 11 and related statutory provisions that will better balance the goals of effectuating the effective reorganization of business debtors - with the attendant preservation and expansion of jobs - and the maximization and realization of asset values for all creditors and stakeholders. ${ }^{39}$

These developments highlight the changing scope of insolvency regimes, from a creditor-bargaining approach in the direction of a social benefit approach. No longer are the creditors' interests the sole interests that are taken into consideration; this is expanded to include a wider variety of interests.

35. See, inter alia, EIR 2015, Recitals 63 and 72; Article 13.

36. Commission Recommendation of 12.3.2014 on a new approach to business failure and insolvency (2014/135/EU), Recital 1 ('2014 Recommendation'). In addition, Recital 12 states: 'removing the barriers to effective restructuring of viable companies in financial difficulties contributes to saving jobs and also benefits the wider economy'.

37. UNCITRAL Model Law on Cross-Border Insolvency Law (1997) with Guide to Enactment and Interpretation (2013), available at: <http://www.uncitral. org/uncitral/en/uncitral_texts/insolvency.html $>$. See also Bob Wessels and Gert-Jan Boon, 'Cross-Border Insolvency Law: International Instruments and Commentary' (2nd edn) (Kluwer Law International, 2015), paragraph 8.

38. Ibid., paragraphs 69 and 161 .
39. American Bankruptcy Institute Commission to Study the Reform of Chapter 11 (2012-2014), Final Report and Recommendations (2014) ('ABI Final Report'), 3, available at: <http://commission.abi. org/final-report $>$. The necessity of and the approach to better balance the interests of all stakeholders has, however, been disputed by, for example, the Loan and Syndications and Trading Associations (LSTA) who argue that Chapter 11 is currently sufficiently supporting the interests of all involved stakeholders: LSTA, The Trouble with Unneeded Bankruptcy Reform: The LSTA's Response to the ABI Chapter 11 Commission Report (2015), 35, 36, 46 and 55. See also Bob Wessels and Rolef de Weijs (eds), International Contributions to the Reform of Chapter 11 U.S. Bankruptcy Code (European and International Insolvency Law Studies 2) (Eleven International Publishing, 2015). 


\section{B. The shifting focus of EU harmonisation of insolvency}

At the EU level, the focus has shifted from ad hoc harmonisation to procedural harmonisation and substantive harmonisation. Up until 2000, only ad hoc harmonisation of insolvency matters was observed in EU law. Take, for example, the Transfer of Undertakings Directive, the European Travel Directive and also the Directive on Employer Insolvency ${ }^{40}$ which include harmonisation of certain aspects of insolvency. This approach resulted in a diverse treatment of insolvency related matters.

A next stage was reached with the adoption of the EIR 2000, which brought procedural harmonisation of cross-border insolvency proceedings. From 2011 onwards, discussions started on further harmonisation of EU insolvency law. This included a revision of the EIR 2000 and, in particular, harmonisation of certain elements of substantive insolvency laws. Regarding the latter, the Commission presented its 2014 Recommendation on 12 March $2014^{41}$ and, in November 2016, a proposal for a Restructuring Directive. When successful, this will be a third stage in the Europeanisation of insolvency law. It is important to note the increasing invasiveness of European legislation which, without doubt, will result in increased interest from many (affected) stakeholders. ${ }^{42}$

\section{Rescuing distressed businesses}

Over the past two decades, a paradigm shift has taken place in legislative reforms by moving away " $[\ldots]$ from the sacrosanct "pay what you owe" to the balanced promotion of the continuity of companies in distress [...] ${ }^{43}$ The EIR 2015 also embraces the rescue perspective, as can be derived, for example, from the expanded scope of insolvency proceedings of this regulation but also that secondary proceedings can be a liquidation or restructuring proceeding or the option for the insolvency practitioner to give an undertaking. ${ }^{44}$ Also, in the Recommendation, the European Commission has shown its dedication to harmonise substantive insolvency law, in particular, to 'restructure [financially distressed but economically viable businesses] at an early stage with a view to preventing their insolvency, and therefore maximise the total value to creditors, employees, owners and the economy as a whole.' ${ }^{45}$ The involvement of concerned stakeholders may be a necessary and sensible consequence.

40. Originally adopted as Directive 77/187/EEC on the approximation of the laws of the Member States relating to the safeguarding of employees' rights in the event of transfers of undertakings, businesses or parts of businesses; Council Directive 90/314/EEC of 13 June 1990 on package travel, package holidays and package tours; and Council Directive 80/987/ EEC of 20 October 1980 on the approximation of the laws of the Member States relating to the protection of employees in the event of the insolvency of their employer.

41. For a commentary on the 2014 Recommendation, see Stephan Madaus, 'The EU Recommendation on
Business Rescue - Only Another Statement or a Cause of Legislative Action Across Europe?' (2014) 27(6) Insolvency Intelligence 81.

42. On the three stages of the Europeanisation of insolvency law, see also Bob Wessels, 'On the Future of European Insolvency Law' in Rebecca Parry (ed), European Insolvency Law: Prospects for Reform (INSOL Europe, 2014) (131-158), also published in (2014) 3 International Insolvency Law Review 310.

43. Ibid., 157.

44. EIR 2015, Recitals 10-17; Articles 1, 2(4), 3(2)-(3) and 36 .

45. See 2014 Recommendation, Recital 1. 
This more holistic approach to rescuing distressed (but economically viable) businesses, instead of pure piecemeal liquidation, is also emphasised in the ABI Report of 2014. They stated that:

Chapter 11 works to rehabilitate companies, preserve jobs, and provide value to creditors only if distressed companies and their stakeholders actually use the chapter 11 process to facilitate an in-court or out-of-court resolution of the company's financial distress'. ${ }^{46}$

An integrative approach concerning a wider group of stakeholders is a necessary to effectively rescue businesses, in particular, at an early stage of financial distress. Where out-of-court solutions are employed to rescue the business, trust and support of a company's stakeholders is a prerequisite for successfully restructuring the company both in the short run and in facilitating a sustainable outlook in the long term. Furthermore, it is also argued that the mere involvement of the 'insolvency crowd' in decisions regarding restructuring will lead to better decision making. Drawing on collective intelligence theory, a group instead of individual experts may be more effective in a restructuring. ${ }^{47}$ At the same time, involvement of a wide group of stakeholders in preparing legislation may be effective in evidencing the extent to which substantive harmonisation of insolvency law is feasible and (politically) desirable.

\section{Conclusion}

Several developments have over time increased stakeholder involvement in insolvency legislation and also in the legislative processes. First of all, insolvency regimes expanded their focus to include the interests of stakeholders such as the debtor, employees and civil society, in addition to those of creditors. This has been advocated, in particular, not only in the UNCITRAL Model Law on Insolvency but also in the EIR 2015 and the Commission's Recommendation. Secondly, where harmonisation was characterised by ad hoc efforts until the adoption of the EIR 2000 with procedural harmonisation, the Commission is working toward a next phase of substantive harmonisation of insolvency law. This is a process of increased Europeanisation of insolvency regimes, with increasing affecting various parties. Thirdly, there is a stronger desire to rescue distressed businesses instead of piece-meal liquidation. To achieve a successful restructuring, trust and support from concerned stakeholders is required. Therefore, involvement of stakeholders is necessary too.

The involvement of all concerned stakeholders works especially well with the social benefit approach. With the rescue of a distressed business, the interests in the company of stakeholders are, to a greater or lesser extent, secured with the protection of jobs, human capital, ${ }^{48}$ continuation of trade agreements, payment of taxes and so forth.

46. ABI Final Report, previous note 39, 6.

47. This is illustrated by Stephan Madaus with regard to accepting or rejecting rescue plans: 'On DecisionMaking in Rescue Cases' in Bernard Santen and Dick van Offeren (eds), Perspectives on International Insolvency Law: A Tribute to Bob Wessels (Kluwer, 2014) (215-228).
48. Referred to by Michelle Harner as one of the soft variables that companies possess: 'The Value of Soft Variables in Corporate Reorganizations' (2015) University of Illinois Law Review 509. 


\section{Toward Harmonisation of EU Insolvency and Restructuring Laws}

\section{A. The road toward harmonisation}

Where various developments argue in favour of stakeholder involvement, this was not yet the approach when, in 2011, the European Parliament adopted a resolution requesting the Commission to submit proposals for legislative measures with regard to insolvency proceedings in the context of EU company law (Resolution). ${ }^{49}$ This Resolution was the so-called 'kick-off' for initiatives in which active stakeholder involvement developed over time. The Commission responded initially at the end of 2012 with a 'Communication on a new European approach to business failure and insolvency' (Communication) that emphasised the necessity of a shared European rescue and recovery culture. $^{50}$

On the same day the Commission's Communication went out (12 December 2012), a legislative process also started with the Commission's proposal to revise the EIR 2000. ${ }^{51}$ Two studies were conducted to review the working of the EIR 2000. ${ }^{52}$ An expert group was formed to assist the Commission in the drafting process, ${ }^{53}$ a public consultation was held and two meetings took place with national experts. This contributed to the adoption of the EIR 2015.

On 12 March 2014, the Commission had also published its 2014 Recommendation. In the preparation of the Recommendation, the Commission sought input and commissioned a study to INSOL Europe on national insolvency regimes. ${ }^{54}$ Eighteen months after the issuance of the Recommendation, ${ }^{55}$ the Commission concluded in the evaluation that ' $[\ldots]$ a few Member States have undertaken reforms which, in some cases, resulted in legislation implementing the Commission's Recommendation [...]'. Still, many Member States did not contemplate or launch reforms, sometimes as they consider their regimes in line with the Recommendation. This lead the Commission to conclude that the Recommendation

49. Previous note 1.

50. Communication from the Commission to the European Parliament, the Council and the European Economic and Social Committee, a new European approach to business failure and insolvency, 12.12.2012, COM(2012) 742 final, 3, 5-8.

51. European Commission, Proposal for a Regulation of the European Parliament and of the Council amending Council Regulation (EC) No 1346/2000 on insolvency proceedings, COM(2012) 744 final, Explanatory Memorandum, 4-5.

52. Report from the Commission to the European Parliament, the Council and the European Economic and Social Committee on the application of the Council Regulation (EG) No. 1346/2000 of 29 May 2000 on insolvency proceedings of 12.12.2012, $\mathrm{COM}(2012)$ 743 final, available at:<http://ec.europa.eu/justice/ civil/files/insolvency-report_en.pdf $>$. For the comparative legal study, see Burkhard Hess, Paul Oberhammer and Thomas Pfeiffer, European Insolvency Law, the Heidelberg-Luxemburg-Vienna Report on the Application of Regulation (EG) No. 1346/2000/EG on Insolvency Proceedings (External Evaluation JUST/2011/JCIV/PR/0049/A4) (2013), available at:<http://ec.europa.eu/justice/civil/files/ evaluation_insolvency_en.pdf $>$ (also published as Burkhard Hess, Paul Oberhammer and Thomas Pfeiffer, European Insolvency Law: The HeidelbergLuxembourg-Vienna Report (Beck-Hart-Nomos, 2014).

53. Previous note 30.

54. INSOL Europe, Study on a New Approach to Business Failure and Insolvency - Comparative Legal Analysis of the Member States' Relevant Provisions and Practices (presented to the European Commission) (2014).

55. 2014 Recommendation, Articles 35-36. 
did not have the desired impact. ${ }^{56}$ An Impact Assessment that was published in March 2016 reiterated the same conclusion. ${ }^{57}$

In September 2015, a new initiative was announced with a public consultation on a European capital markets union (GMU), with the aim to promote diversification of and access to the funding needs of businesses. ${ }^{58}$ In the subsequent Action Plan, the Commission considered, out of 20 key actions, 'insolvency' as one of the key actions for a CMU and that a legislative initiative would be prepared in this area. ${ }^{59}$ This resulted in the proposal of the Commission of 16 November 2016 for a Restructuring Directive.

Often for good reasons, substantive harmonisation of insolvency laws has been considered impractical and unfeasible. ${ }^{60}$ However, since 2012, the Commission has shown its dedication to promote the rescue of distressed businesses, although, in particular, the widely diverging national insolvency regimes and (ii) the embeddedness of insolvency law is mentioned as a hindrance to harmonisation.

\section{B. Widely diverging national insolvency regimes}

Over the last few years, several studies on national insolvency regimes have been conducted at the request of the Commission. ${ }^{61}$ They highlight the widely diverging approaches adopted by Member States financially distressed businesses. Also, the evaluation of the Commission's Recommendation shows that Member States have not yet adopted a shared approach. ${ }^{62}$ The Commission too has repeatedly observed that great differences exist between national insolvency regimes, limiting the functioning of the internal market and creating a barrier for harmonisation of EU insolvency and restructuring law. It is stated both in the recitals to the EIR 2000 as well as the EIR 2015 that 'as a result of the widely differing substantive laws it is not practical to introduce insolvency proceedings with universal scope in the entire Community'. 63

\footnotetext{
56. European Commission, Directorate-General Justice \& Consumers of the European Commission, Evaluation of the Implementation of the Commission Recommendation of 12.3.2014 on a New Approach to Business Failure and Insolvency (30 September 2015), 2 and 5.

57. European Commission, Directorate-General Justice (A1), 2016/JUST/025 - Insolvency II, inception Impact Assessment (3 March 2016), 7.

58. Communication from the Commission to the $\mathrm{Eu}-$ ropean Parliament, the Council, the European Economic and Social Committee and the Committee of the Regions, Action Plan on Building a Capital Markets Union, 30.09.2015, COM(2015) 468 final, 3.

59. Ibid., 26 and 30. This was reiterated in European Commission, Communication from the Commission to the European Parliament, the Council, the European Central Bank, the European Economic and Social Committee and the Committee of the Regions, 'Towards the Completion of the Banking Union' (24 November 2015), COM(2015) 587 final, 10.
}

60. See, for example, 'The H-word is out!' observed by Bob Wessels, 'Harmonization of Insolvency Law in Europe' (2011) 8(1) European Company Law 27 et seq. See also Björn Laukemann, 'Structural Aspects of Harmonization in European Insolvency Law' in Jean-François Vandrooghenbroeck et al. (eds), Le Temps et Le Droit: Hommage au Professeur Gilberte Closset-Marchal (Larcier, 2013), 347 et seq.; Christoph Paulus, 'Europeanisation of the Member States' Insolvency Laws' (2015) 3 Nottingham Insolvency and Business Law e-fournal 301 et seq. 61. See Hess et al., previous note 52; INSOL Europe, previous note 54; University of Leeds, Study on a New Approach to Business Failure and Insolvency: Comparative Legal Analysis of the Member States' Relevant Provisions and Practices (2016), available at: $<$ https://publications.europa.eu/en/publication-detail/-/publication/3eb2f832-47f3-11 e6-9c64-

01 aa75ed7 1al/language-en $>$.

62. See previous notes $56-57$.

63. EIR 2000, Recital 11; EIR 2015, Recital 22. 


\section{Embeddedness of insolvency law}

Furthermore, insolvency law is closely intertwined with various fields of law, including company law, contract law, employment law, tax law and security law. ${ }^{64}$ This brings additional complexity in the harmonisation of insolvency related issues on a European level. Therefore, harmonisation might be realised most easily for those topics that are especially (and exclusively) dealt with under insolvency law. ${ }^{65}$ In its 2014 Recommendation, the Commission selected such topics. For a GMU, such efforts may fall short, in that context, we will see proposals that address topics that are at the crossroads of various fields of law, which will, of course, bring additional complexity to the harmonisation efforts.

\section{The Commission's involvement of stakeholders}

With the foregoing in mind, any legislative proposal to substantively harmonise insolvency law will have a significant impact on national insolvency regimes. Therefore, it comes as no surprise that the Commission has sought to interact with stakeholders to fine-tune its Proposal for a Restructuring Directive. Also, involvement and support for any legislative proposal from such a broad group of stakeholders may be compelling for EU Member States too. It is what could be called a horizontal approach where extensive consultation takes place to involve stakeholders (already) in preparation of a legislative proposal, contrary to the traditional vertical approach where stakeholder involvement relates mostly to consultation on a published legislative proposal.

The Commission employed various activities in which stakeholders are involved, this includes among others:

- Discussions with a group of experts on restructuring and insolvency law. ${ }^{66}$ This group, established in 2015 and expected to continue until 2018, consists of 22 individual experts and four institutional observers. These are what the Commission calls 'type A' and 'type E' members. ${ }^{67}$ The individual experts are practitioners, academics and judges from mostly western European countries and are appointed based on their personal capacity. Observers are public entities, mostly international organisations. The experts assist the Commission directly in drafting the legislative proposal. Also, they assist the Commission in its coordination and cooperation with both Member States and stakeholders. ${ }^{68}$ These groups, in the field of insolvency (a previous group on cross-border insolvency was

64. See, for example, European Parliament, 'Harmonisation of insolvency law at EU level, note', European Parliament 2010, PE419.633, 27; Bob Wessels, 'Harmonisation of Requirements for Insolvency Holders on a European Level' in Reinhard Bork, Goehard Kayser and Frank Kebus, Festschrift für Bruno M. Kübler zum 70. Geburtstag (Beck, 2015), 760. 65. Laukemann, previous note 60, 348.

66. Previous note 30. Reports of the expert group's meetings are published at this website. The group consists of 22 experts (comprising academics, judges and practitioners) and two international organisations.
With regard to the functioning of expert groups they are guided, since 2010, by a Communication from the President to the Commission, Framework for Commission Expert Groups: Horizontal Rules and Public Register, C(2010) 7649 final that was revised in 2016 with the Commission Decision of 30.05.2010 establishing horizontal rules on the creation and operation of Commission expert groups, C(2016) 3301 final ('Commission Decision 2010').

67. Commission Decision 2010, Article 7(2).

68. Ibid., Article 3(1)(c). 
initiated to assist on the revision of the EIR 2000), ${ }^{69}$ are established for specific matters only and usually operate on a temporary basis. With the increasing involvement of the Commission in insolvency law, establishing a permanent expert group on insolvency law could be considered. ${ }^{70}$

- Stakeholder meetings. In the course of 2016, the Commission organised several meetings with diverse stakeholders to discuss the possibilities for a new legislative proposal on insolvency. Three informal stakeholder meetings took place in April, May and July, which functioned as a sounding board for the Commission. ${ }^{71}$ In addition, on 12 July 2016, a conference, hosted by the Commission and under the auspices of the Slovak Presidency of the Council, was held on convergence of insolvency frameworks within the European Union. This conference was attended by some 250 representatives of national governments, national parliaments, European Commission, European Parliament, courts, insolvency practitioners, business associations, consumer associations, academia, lawyers, banks, trade unions and labour unions. ${ }^{72}$

- Public consultations on an effective insolvency law within the EU. The Commission conducted two public consultations where harmonisation of insolvency laws was considered. Firstly, in 2015, with regard to the CMU, a public consultation was conducted in which one question touched upon harmonisation of insolvency. Secondly, in 2016, after it was announced that a legislative proposal would be prepared, an in-depth consultation on harmonisation of insolvency law was conducted. These public consultations will be discussed more extensively in Section VI.

The aforementioned examples of stakeholder involvement took place in 2015 and 2016, in the phase where the Commission has been preparing the proposal for a Restructuring Directive and where no draft texts were publicly available. The Commission will need to consider whether further involvement of stakeholders is beneficial and does not bring unintended influence on the legislative process. It is not clear whether (certain) stakeholders will be involved now the proposal has been published and the legislative process is on its way. ${ }^{73}$ Besides the group of experts, which is expected to continue until $2018,{ }^{74}$ no further details have been announced.

\section{E. Conclusion}

Since the 2011 Resolution of the European Parliament, the Commission has been dedicated to promoting the rescue of financially distressed but economically viable

69. Previous note 30 .

70. In contrast to, for example, company law (Group E01456), there is no permanent expert group on insolvency law.

71. These meetings took place on 7 April 2016, 27 May 2016 and 18 July 2016. The minutes of the meeting of the informal stakeholder group were published and made available (temporarily) at the website of the Commission. Participants of these meetings included BusinessEurope, AFME, EBF, ACCA, UEAPME, ESBA, Independent Retail Europe, EuroChambers, ETUC, EFIN, FEE, INSOL Europe, FDG, The Council of Bars and Law Societies of Europe and the European Law Institute.
72. For more information on this event, see: http://ec. europa.eu/newsroom/just/item-detail.cfm?item_id= 30874. A video recording of the conference is available at: https://webcast.ec.europa.eu/insolvencyconference\#.

73. In the legislative process, several steps have been made. For more information, see <http://eur-lex.europa.eu/legal-content/EN/HIS/?uri= CELEX:52016PC0723>.

74. See the Call for a Group of Experts on insolvency and restructuring, available at <http://ec.europa.eu/ transparency/regexpert/index.cfm?do=groupDetail. groupDetail\&groupID $=3362>$. 
businesses. This has resulted, in particular, in a Communication (2012), a Recommendation (2014) and a legislative proposal in (2016). Until 2015, the involvement of stakeholders has been limited. Besides some studies and an expert group, stakeholders' involvement was limited. At the same time, not only studies on national regimes but also analyses of the Commission and the European Parliament pointed out that any legislative effort in this regard would be complex. This is, in particular, due to (i) the widely differing national insolvency regimes and (ii) the great extent to which insolvency law is intertwined with other fields of law. Therefore, harmonisation efforts will touch upon the interests of many affected stakeholders. This is also why the involvement of stakeholders by means of expert groups, stakeholder meetings and public consultations, comes as no surprise. This involvement took off especially after the preparation of a legislative proposal was announced. It is not clear in what way stakeholders remain involved, except for the group of experts that will continue to assist the Commission until 2018.

\section{Stakeholder Sentiments: The Public Consultations on CMU and on an Effective European Insolvency Framework}

The Commission conducted two public consultations, in 2015 and 2016, that considered insolvency. They show what the targeted audience is of the Commission, what topics they are requested to respond too, what types of respondents are involved and what their positions are. Both consultations will be briefly described.

\section{A. Public consultation on building a capital markets union}

In 2015, with regard to the $\mathrm{CMU},{ }^{75}$ the Commission surveyed on harmonising insolvency laws in Europe. ${ }^{76}$ In the public consultation, it was asked to respondents: 'What specific aspects of insolvency laws would need to be harmonised in order to support the emergence of a pan-European capital market?"77 The consultation, which was open to all citizens and organisations, resulted in some 422 responses from a wide variety of stakeholders. ${ }^{78}$ The wording of several respondents

\footnotetext{
75. Previous note 58.

76. Public Consultation: Building a Capital Markets Union (18 February 2015-13 May 2015), for which see <http://ec.europa.eu/finance/consultations/ 2015/capital-markets-union/index_en.htm>.

77. This public consultation ran from 18 February 2015 to 13 May 2015 and was based on the Commission's Green Paper 'Building a Capital Markets Union, 19.02.2015'. The responses to the questionnaire were made available at <https://ec.europa.eu/eusurvey/ publication/capital-markets-union-2015?

surveylanguage $=\mathrm{en}>$. A summary of the responses is provided in Commission Staff Working Document, Feedback Statement on the Green Paper 'Building a Capital Markets Union' accompanying the document Communication from the Commission to the European Parliament, the Council, the European Economic and Social Committee and the Committee of the
}

Regions, Action Plan on Building a Capital Markets Union of 30.9.2015, SWD(2015) 184 final ('Feedback Statement'), for which see <http://ec.europa.eu/finance/consultations/2015/capital-markets-union/ docs/summary-of-responses_en.pdf $>$.

78. In total, some 422 respondents from across the 27 Member States and beyond submitted a response on the 32 questions of this consultation (346 responses were made public). This includes (representatives of) Member States and Ministries (of Finance), nongovernmental organisations, international or European organisations, industry/business associations, trade unions, companies, SMEs, microenterprises, sole traders, private individuals, banks, pension funds, central banks, capital market regulators and supervisors, consumer organisations, think tanks and research institutes. 
appeared similar, although submitted by different organisations. For instance, this can relate to a 'professional' organisation preparing multiple responses for specific stakeholders or indicate some sort of manipulation of the outcomes.

The Commission concluded from the responses that a lack of harmonised insolvency law is regarded as one of the main barriers to bank and non-bank direct lending to companies and that harmonisation of certain aspects of insolvency law is recommended. ${ }^{79}$ The stakeholders that took part in this public consultation took varying positions on harmonisation ${ }^{80}$ :

- Banks favour reform of certain aspects of national insolvency regimes at the EU level.

- Pension funds and other financial intermediaries noted that the diverging national insolvency laws should be reformed, but this is a long-term project.

- Member States and Ministries of Finance were hesitant about harmonisation. They might consider a step-by-step approach in increasing approximation of national insolvency laws, possibly accompanied by measures to strengthen national insolvency frameworks.

- Central Banks showed support for a more comprehensive reform of the diverging national insolvency regimes.

- Capital Market Regulators similarly expressed support for a reform of insolvency regimes, as the current differences create barriers to cross-border investments.

- Business Associations showed diverse responses on the harmonisation of insolvency laws.

- SME Representatives expressed that efficiency and effectiveness of insolvency practitioners and courts could be improved with harmonisation.

- Labour unions support a wide-ranging harmonisation of insolvency frameworks.

- Research Institutes favour harmonisation to realise better reallocation of capital and bring more economic growth.

In general, stakeholders expressed support for (partial) substantive harmonisation of insolvency law. ${ }^{81}$ However, Member States and Ministries of Finance seemed more cautious (Figure 2). Out of the 12 substantive responses from Governments and Ministries, ${ }^{82}$ five showed some interest to further study possibilities for partial harmonisation, including Austria, the Czech Republic, Germany, the Netherlands and Sweden. Other responses stated that harmonisation would not be desirable or that current measures would suffice. ${ }^{83}$

The respondents to the public consultation made various suggestions for specific topics that would be ready for harmonisation. They suggested, among others, the following topics:

79. Feedback Statement, previous note 77, 2.6; Annex Q 5.6, Q15.1, Q16.1, Q19.1, Q24, Q27.1, Q27.2 and Q29.

80. Ibid., at Q29.3.

81. From the 346 public responses, about $25 \%$ of the responses showed support (to some degree) for substantive harmonisation, against less than $10 \%$ of the respondents stating substantive harmonisation would not be desirable or possible (considering the great divergences among countries). Most of the remaining respondents did not answer Q29 on harmonisation of insolvency law.
82. Responses were received from several Governments/Ministries. Those from Austria, Czech Republic, Estonia, Finland, France, Germany, States of Guernsey, Hungary, Ireland, Isle of Man, Italy, Jersey, Lithuania, Netherlands, Norway, Slovakia, Sweden and the United Kingdom were published. Only 12 responses touched upon the issue of harmonisation of insolvency law, while six responses provided no answer.

83. Feedback Statement, previous note 77, Annex Q29. 


\section{Response to harmonisation}

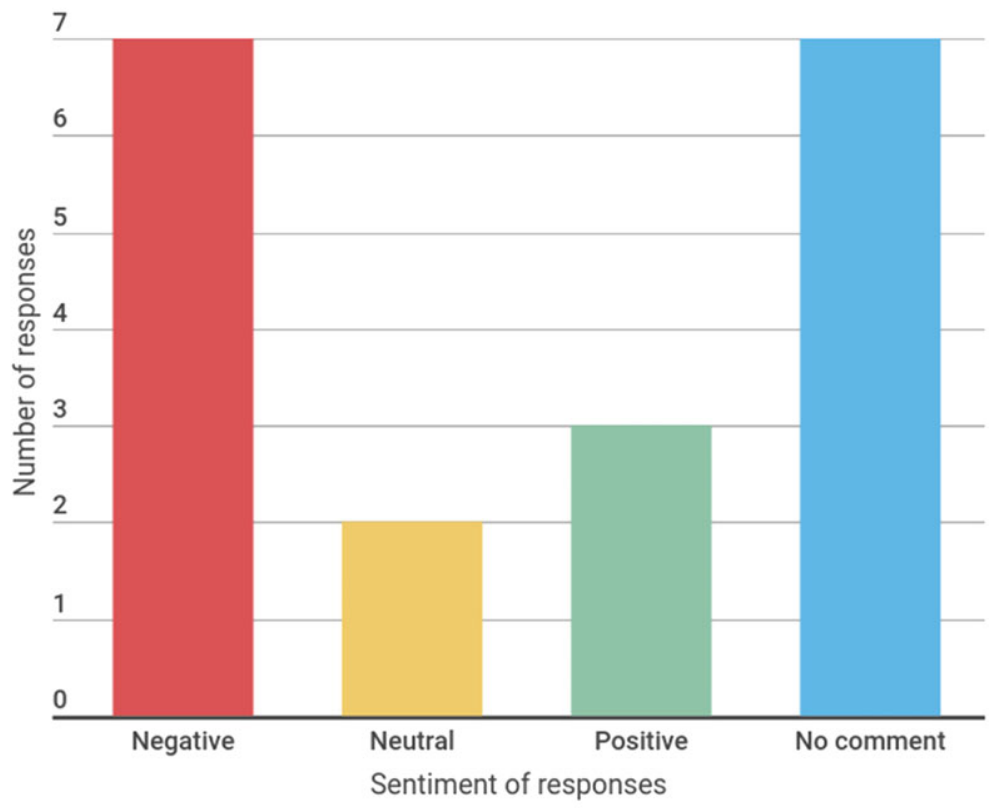

Negative

Neutral

Positive

No comment

Figure 2. Sentiments of Member States and Ministries of Finance toward harmonisation.Source: Author's Own. [Colour figure can be viewed at wileyonlinelibrary.com]

- Common definitions of, for example, default, avoidance actions, restructuring of companies, stay on individual creditor claims, discharge period and close-outnetting;

- Preventive restructuring proceedings, out-of-court and hybrid restructuring proceedings;

- Communications on the opening of insolvency proceedings and the measures to be taken upon commencement;

- Requirements for opening insolvency proceedings;

- Ring-fencing of a client's securities (for insolvent financial intermediaries);

- Ranking of creditor's claims;

- Qualifications, tasks and rights of insolvency practitioners

- Liability of directors and shadow directors;

- Time cap on insolvency proceedings;

- Establishment of an EU register with information on insolvencies;

- A single form for the petition of claims;

- Second chance for entrepreneurs; and

- Personal insolvency.

From the responses, the Commission derived that insolvency proceedings are considered a key barrier to a CMU, especially as inefficiency and the great diversity of national insolvency regimes inhibit the possibility to assess the risks associated with making cross-border investments. It was commented often that the 
harmonisation is not only complex, in particular due to its embeddedness in other fields of law, but also a long-term rather than short-term endeavour.

\section{B. Public consultation on effective insolvency frameworks}

For a period of 12 weeks (23 March 2016 to 14 June 2016), the Commission also held a public consultation directed at distinguishing the barriers to effective insolvency frameworks within the EU. The consultation was open to the 'views and input from the broadest public possible', including 'citizens, companies (including SMEs and entrepreneurs), business associations, public authorities, consumer organisations, as well as insolvency practitioners, researchers and think tanks, courts and public administrative bodies at international, EU-wide, national, regional and/or local levels' it resulted in over 260 respondents. $^{84}$

The consultation has predominantly an explorative character, as the results would be used to devise relevant topics for the Commission's legislative proposal. The consultation related to 'efficient organisation of debt restructuring procedures' and 'the rationale and the process for debt discharge for entrepreneurs (and its possible extension to consumers) ${ }^{8}{ }^{85}$

The topics of the consultation are based, in particular, on the 2014 Recommendation and include among others ${ }^{86}$ :

- Effect of differences between the laws of the Member States, in particularly at newly established companies and saving distressed but viable companies;

- Involvement of courts in restructuring procedures;

- Publicity for restructuring procedures;

- Assessment of the viability of a distressed debtor;

- Debtor-in-possession;

- Stay;

- Adoption of restructuring plan and cram-down;

- Protection of rescue finance;

- Directors' liability;

- Second chance for over-indebted honest debtors (entrepreneurs and consumers);

- Recovery of debts, including ranking of claims and avoidance actions;

- Professional standards for insolvency practitioners; and

- Disqualification of debtors.

A summary of the results is published by the Commission and shows that Member States take a different position to the other stakeholders, in line with the earlier public consultation on the CMU. The Member States, in general, preferred a

84. Consultation on an effective insolvency framework within the EU from 23 March 2016-14 June 2016, for which see <http://ec.europa.eu/justice/newsroom/ civil/opinion/160321_en.htm >. The Commission reported on this public consultation in its proposal for a Restructuring Directive. There were over 260 respondents from the 27 Member States.
85. Idem. See also the introduction to the questionnaire of the public consultation itself.

86. Questionnaire for the public consultation on an effective insolvency framework within the EU. Responses to the consultation could also be submitted by (e-)mail to the DG Justice, Unit Al - Civil Justice Policy. 
principle-based approach, as the embeddedness of insolvency laws prevents more substantive harmonisation at this point. Other stakeholders were in favour of a framework with minimum rules on early recourse for distressed businesses and a second chance for honest bankrupt entrepreneurs. ${ }^{87}$

\section{Conclusion}

From the public consultations in 2015 and 2016 on insolvency, the observation may be made that, in general, there is support for furthering the adoption of a European insolvency framework. The major divergences between the regimes of Member States create a barrier for harmonisation, as well as the embeddedness of insolvency law. At the same time, it necessitates action from the Commission in order to promote the free flow of capital across the EU as well as the assessment of investment risks.

Support for this is given by a variety of stakeholders, including banks, central banks, capital market regulators, business associations, labour unions and research institutes, which are mostly the so-called dormant and discretionary stakeholders. However, Member States and Ministries of Finance (which can be classified as dominant stakeholders) seem to lack ambition and support for substantive harmonisation. They appear more reluctant and sometimes dismissive in (further) legislative efforts in this area. Perhaps, this could have been derived already from not only the mild adoption of the Commission's Recommendation but also national political considerations can play a role here.

\section{The Way Forward with Stakeholders}

The previous conclusion leads to the (for some not so surprising) observation that expectations for a harmonisation of EU insolvency and restructuring law should not be too farfetched. However, the support of various stakeholders, especially from practice, may promote the Commission's initiative with, for example, Member States. Where a standstill in the legislation might still be risked, the Commission could draw on several experiences from other fields where the use of soft law has been considered. This would be in line with the 'open method of coordination', as suggested by Ian Fletcher and Bob Wessels, where traditional hierarchical legislation is supported by soft-law instruments. ${ }^{88}$ Two examples may be provided to illustrate how soft law can assist the insolvency endeavour.

87. Restructuring Directive, Explanatory Memorandum, 17.

88. Fletcher and Wessels, previous note 2, paragraphs 146 and 216. See also <http://eur-lex.europa.eu/ summary/glossary/open_method_coordination. html $>$.

Copyright (C) 2018 INSOL International and John Wiley \& Sons, LtdＩnt. Insolv. Rev., Vol. 27: 150-177 (2018) DOI: $10.1002 /$ iir 


\section{A. Inspiration from the Mediation Directive}

The EU Mediation Directive is aimed at securing better access to justice by promoting amicable settlement of all cross-border civil and commercial disputes as well as providing a predictable legal framework. ${ }^{89}$ In 2016, an evaluation was performed of the 2008 Mediation Directive. ${ }^{90}$ In advance, the Commission conducted a public consultation that resulted in over 500 responses from interested individuals, mediators, judges, lawyers, other legal practitioners, academics, public authorities and Member States. ${ }^{91}$ The evaluation shows that the Mediation Directive has functioned as an 'impetus to a wider take-up of mediation also in a purely domestic context across the EU, ${ }^{92}$ Still, difficulties arise with regard to the functioning of national mediation systems and further improvement would be required.

In the area of insolvency, more importantly, the Commission reminds that the Mediation Directive would also apply to restructurings. The Commission recommend appointment of mediators by courts to support the negotiation of a restructuring plan. However, at the same time, the Commission concluded that mediation in insolvency proceedings has remained underdeveloped. ${ }^{93}$

The evaluation showed that the Mediation Directive has been implemented in different ways and that stakeholder positions are diverse on what further action to take. ${ }^{94}$ Member States were reluctant to implement additional legislation. In particular, practitioners were supportive of further legislative action relating to, for example, quality standards for mediation services and making mediation compulsory in certain types of disputes. ${ }^{95}$ The Commission made the recommendation to Member States to further the implementation of the Mediation Directive and point out best practices for Member States and practitioners. ${ }^{96}$ This may not be surprising as mediation is governed in many EU jurisdictions by codes of conduct. ${ }^{97}$ However, it shows a practical solution to provide practitioners with room for approximation of national regimes.

89. Directive 2008/52/EC of the European Parliament and of the Council on certain aspects of mediation in civil and commercial matters; Report from the Commission to the European Parliament, the Council and the European Economic and Social Committee on the application of Directive 2008/52/EC of the European Parliament and of the Council on certain aspects of mediation in civil and commercial matters, $26 \mathrm{Au}-$ gust 2016, COM(2016) 542 final ('Mediation Report'), paragraphs 1.1 and 4 .

90. Mediation Report, previous note 89.

91. Ibid., paragraph 1.3.

92. Ibid., paragraph 4.

93. Ibid., paragraph 3.2. See also Bob Wessels, 'Mediation in Restructuring and Insolvency' (2016) July(3) Tijdschrift voor Arbitrage 59.

94. Ibid., paragraphs 2 and 4.
95. Ibid., paragraphs 3.3.1 and 3.6.

96. Ibid., paragraph 4 . These best practices concern: '[...] requirements for parties to state in their applications to courts whether mediation has been attempted, in particular in family law matters obligatory information sessions within the framework of a judicial procedure and an obligation on courts to consider mediation at every stage of judicial proceedings, financial incentives making it economically more attractive for parties to use mediation instead of resorting to judicial proceedings, ensuring enforceability without necessarily requiring the consent of all parties to the agreement.

97. Ibid., paragraph 3.3.1 see in particular the European Code of Conduct for Mediators, available at $<$ http://ec.europa.eu/civiljustice/adr/adr_ec_ code_conduct_en.pdf $>$. 


\section{B. Inspiration from Recital $\mathbf{4 8}$ of the European Insolvency Regulation (recast)}

Another example of semi-legislation was incorporated in the EIR 2015. Here, obligations for cooperation and communication have been extended significantly. Not only insolvency practitioners but also courts must cooperate and communicate closely with each other in cross-border insolvency cases. ${ }^{98}$ In Recital 48 EIR (recast), the EIR 2015 left room to further specify these obligations:

[...] When cooperating, insolvency practitioners and courts should take into account best practices for cooperation in cross-border insolvency cases, as set out in principles and guidelines on communication and cooperation adopted by European and international organisations active in the area of insolvency law, and in particular the relevant guidelines prepared by the United Nations Commission on International Trade Law (Uncitral).

The EU legislator has given explicit room to groups of European or international stakeholders to develop further guidance on communication and cooperation for insolvency practitioners and courts. This novelty in the field of European insolvency law can be an effective approach to allow for a sort of harmonisation based on self-regulation of stakeholders by means of principles and guidelines, which function within the scope of an EU legislative instrument.

Formulating such provisions should receive considerable attention. Recital 48 of the EIR 2015, for example, states that in particular, the guidelines prepared by UNCITRAL are relevant. Remarkably, UNCITRAL has provided no 'guidelines' with regard to communication and cooperation. It is therefore not clear what the EU legislator is referring to. Perhaps it is the UNCITRAL Model Law, whose Articles 25-27 relate to cooperation and communication in cross-border insolvency cases. ${ }^{99}$ At the same time, the EIR 2015 may refer to the UNCITRAL Practice Guide on Cross-Border Insolvency Cooperation (2009) that provides, for example, insights on cooperation and sample clauses for insolvency agreements (also known as protocols). ${ }^{100}$ Alternatively, it could refer to the UNCITRAL Model Law on Cross-Border Insolvency: The Judicial Perspective (2013) that provides some guidance to courts on cooperation and communication. Therefore, the EU legislator should provide stakeholders with clear directions on the scope, status and adoption of principles and guidelines. ${ }^{101}$

\section{Conclusion}

Where support from Member States (dominant stakeholders) may be lacking for substantive harmonisation of insolvency law, despite the support from dormant

98. EIR 2015, Articles 41-44. For group proceedings, comparable obligations have been provided for insolvency practitioners and courts, for which see EIR 2015, Articles 56-59.

99. Wessels and Boon, previous note 37, paragraph 8. 100. UNCITRAL Practice Guide on Cross-Border Insolvency Cooperation (2009), available at: <http:// www.uncitral.org/uncitral/en/uncitral_texts/insolvency.html>; Wessels and Boon, previous note 37, paragraph 11.

101. UNCITRAL Model Law: The Judicial Perspective (2011), available at: <http://www.uncitral.org/ uncitral/en/uncitral_texts/insolvency.html >; Wessels and Boon, previous note 37, paragraph 14. 
and discretionary stakeholders, we could draw from experiences in other fields. Here, examples with regard to soft law show how the EU legislator can involve stakeholders, also in executing EU law by creating room for non-binding principles and guidelines on matters where EU legislation is absent.

These examples include the 2016 evaluation of the Mediation Directive where Member States were reluctant to introduce additional legislation, but other stakeholders were supportive of further legislative action. The Commission decided recommended that recommendations and best practices should be proposed to Member States and practitioners to promote further approximation. Another example relates to the EIR 2015, where Recital 48 leaves room for self-regulation by European and international organisations. It states - in brief - that such organisations may develop guidelines and recommendations to support insolvency practitioners and courts in communication and cooperation in cross-border insolvency cases. Within the scope of an EU instrument and, within certain conditions, stakeholders are permitted to develop principle and best practices.

These examples illustrate alternatives for the EU legislator when support for (specific parts of) harmonisation is lacking. Stakeholders, in particular from practice and academia, could develop such principles and best practices to further specific elements of an effective restructuring framework for distressed businesses in Europe.

\section{Conclusion}

In its preparatory work for a legislative proposal on substantive harmonisation of insolvency laws in Europe, the European Commission has given stakeholders a prominent role. However, it remained undecided not only who these stakeholders are, why the Commission is involving them but also whether and to what extent it is justifiable to involve them in a legislative process.

In Sections II and III, elaboration was made on what stakeholders are, in particular, regarding the Commission's legislative governance and how different stakeholders can be distinguished and prioritised in the field of insolvency law. Following the definition proposed by Savage et al., stakeholders need (i) to have an interest in the actions of an organisation, which arguably is present when an organisation's actions affect these interests and (ii) be able to influence the organisation. The Commission does not apply a formal approach to these dimensions of stakeholders, as also non-legislative parties are involved in its activities and are therefore also considered a stakeholder. For the legislative activities on harmonisation of insolvency law, stakeholders can be defined as:

all those individuals, groups and other organisations that have an interest in the EU legislative process of harmonising insolvency and restructuring law and which have the ability to influence the choices and decisions the Commission has to make.

With the Commission's broad perspective on stakeholders, differentiation of stakeholders is even more complex. Distinguishing and prioritising of interest can 
be based on the salience of interests. Salience can be reviewed on the basis three attributes: (i) power, (ii) legitimacy and (iii) urgency. Urgency will, in general, not be an attribute likely present for stakeholders in a legislative process. Prioritising of interests, without prejudice to specific interests, can be based on the number of attributes they possess. This leads to three types of stakeholders in the legislative process of the Commission:

1 Dominant stakeholders: they possess both power and legitimacy. This includes foremost formal legislative bodies, such as the Council and the European Parliament.

2 Discretionary stakeholders: they possess legitimacy. It relates not only to direct and indirect parties involved in insolvency proceedings, such as debtors, creditors and employees, but also insolvency practitioners and trade unions.

3 Dormant stakeholders: they possess power. This group includes not only academics, the Commission's expert group, but also international organisations such as the International Monetary Fund, UNCITRAL and the World Bank.

The emerging role of stakeholders in the field of insolvency law was discussed in Section IV. Insolvency regimes around the world have shifted their focus, in general, from a creditor's bargaining approach toward a more social benefit minded approach with room for the interests of creditors and other stakeholders. At a European level, insolvency law is no longer treated on an ad hoc basis. The EIR 2000 (and the EIR 2015) brought harmonisation of mainly procedural rules and, since 2011, efforts are made to harmonise also substantive insolvency laws. Such a legislative process will be more invasive on the interests of both creditors and other stakeholders. This is especially true where insolvency regimes are moving away from liquidation toward promoting restructuring. Therefore, an integrative approach concerning all stakeholders is recommended to draft a European legislative proposal to restructure businesses, in particular, at an early stage of financial distress.

Although there are multiple reasons that argue for stakeholder involvement, in Section V, the argument was made that this was not the approach from the start. The debates on harmonising substantive insolvency law started with a resolution of the European Parliament in 2011. In the preparation of the Commission Recommendation (2014) on a new approach to business failure and insolvency and the EIR 2015, several studies were completed. In these efforts, the Commission was supported not only by extensive studies on the EIR 2000 but also a temporary group of experts and meetings with national experts.

In 2015, subsequent to the evaluation of the Recommendation, the Commission published the Action Plan on a CMU and announced a legislative proposal on harmonising substantive insolvency law. From here on, stakeholders were actively involved by the Commission. In previous years, it was observed already repeatedly that substantive insolvency laws of the Member States are widely differing across Europe. Also, insolvency laws are intertwined with various other fields of law, including securities law, labour law, contract law, company law and tax law. The Commission initiated a new (temporary) group of experts to assist in the preparations for the legislative proposal. From April till July 2016, multiple meetings were

Copyright (C) 2018 INSOL International and John Wiley \& Sons, LtdＩnt. Insolv. Rev., Vol. 27: 150-177 (2018) DOI: $10.1002 /$ iir 
organised for extensive debate with a broad variety of stakeholders on the possibilities for harmonisation. Also, public consultations were conducted to gather insights from the wider public. These efforts have led to ample response from stakeholders.

In Section VI, it was shown that there are two main sentiments from stakeholders with regard to harmonisation, which can be derived from the public consultations conducted on the GMU and an effective insolvency framework within the EU. Member States showed reluctance to substantively harmonise insolvency laws, general principles are welcomed, but further harmonisation is considered not yet feasible. At the same time, other stakeholders, including central banks, pension funds, Member States, business associations, SME representatives, labour unions and research institutes, are supportive of a minimum framework to rescue distressed businesses and provide a second chance to honest bankrupt entrepreneurs.

Finally, in Section VII, this article proposes that the current sentiment of all stakeholders does not prevent the Commission from furthering approximation of insolvency frameworks. Before, the Commission experienced similar situations with diverging perspectives of stakeholders and where different approaches with soft law were adopted. Firstly, a public consultation prior to the 2016 evaluation of the Mediation Directive showed that Member States were reluctant to pursue further harmonisation, whereas other stakeholders, in particular practitioners, would favour this harmonisation. The Commission decided to recommend the adoption of best practices and guidelines would be suitable to achieve the desired improvements by practitioners. Secondly, inspiration could be drawn from the EIR 2015. In this regulation, Recital 48 allows for European or international organisations to adopt principles and guidelines to further cross-border insolvency cooperation and communication of insolvency practitioners and courts. These examples illustrate how promoting effective European restructuring frameworks for distressed business may be given shape by means of semi-legislation, even where stakeholder perspectives are diverging. With guidance from the EU legislator, there could be room in legislative measures for contributions from stakeholders.

It can be concluded that stakeholders have become more important for the EU legislator in designing and executing EU legislation in the area of insolvency and restructuring. Concerns have been raised regarding undesired involvement of stakeholders, in particular, commercial market players, in legislative processes. But at the same time, stakeholders may contribute to prioritising potential themes for harmonisation based on perceived needs in practice, a focused treatment of the scope and details of those needs and a higher level of involvement in law making and its execution. The Commission has, in developing a proposal for a Restructuring Directive, decided to involve stakeholders right from the start and in multiple ways. They have been given a prominent role in discussing what a feasible and desirable direction is for a draft legislative proposal. As a result, involvement of stakeholders may lead to better founded legislation. 